Original Article

\title{
INVESTIGATION OF NUTRITIONAL AND ANTIOXIDANT PROPERTIES OF ANATOLIAN BEE BREAD
}

\author{
Mehmet Beykaya ${ }^{1 *}$ \\ Aslı E. Tanuğur Samancı \\ Taylan Samancl ${ }^{2}$ \\ Elif Yorulmaz Önder ${ }^{3}$ \\ Emine M. Uzun ${ }^{3}$ \\ Fatih Tosun ${ }^{4}$ \\ 'Ankara Yıldırım Beyazıt University, Ankara, Turkey \\ 2SBS Bilimsel Bio Çözümler San ve Tic A.Ș., Istanbul, Turkey \\ ${ }^{3}$ SBS Bilimsel Bio Çözümler R\&D Center, Istanbul, Turkey \\ ${ }^{4}$ Republic of Turkish Ministry of Agriculture and Forestry, Ankara, Turkey \\ *corresponding author: mb-kaya@hotmail.com \\ Received: 22 January 2021; accepted: 17 June 2021
}

\section{Abstract}

Bee bread is a bee product produced by bees in which they combine pollen with their digestive enzymes and place them in the comb cells. In this study, it was aimed to evaluate the nutritional and antioxidant properties of Anatolian bee bread and present an examination of regional differences. In order to emphasize the bioavailability of bee bread and to determine its phenolic, flavonoid content, antioxidant activity and nutritional quality, ten samples were collected from different parts of Anatolia. Seven of them were from Muğla (prominent city in terms of honey production), one was from Van representing the Eastern Anatolia region, one was from Sivas representing the Central Anatolia region and one was from Kırșehir. Ten samples were analyzed for total phenolic, flavonoid, antioxidant and moisture content, and the mixture representing ten samples were analyzed for nutritional content (carbohydrate, fat, saturated fat, fiber, protein, salt, ash, iron and zinc). Total phenolic content, flavonoid, antioxidant content and moisture content of the samples were determined as $11.90-14.77 \mathrm{mg} \mathrm{GAE} / \mathrm{g}, 1.30-6.30 \mathrm{mg} \mathrm{CE} / \mathrm{g}$, 20.03-35.43 mg TEAC/g and 10.13-18.10\%, respectively. The highest phenolic, flavonoid and antioxidant content was observed in Muğla2 samples. The study's results were compared to results found in literature, and it was concluded that Anatolian bee bread has high antioxidant content and nutritional value, especially, in terms of carbohydrates, iron and zinc.

Keywords: antioxidant, bee bread, flavonoid, nutrition, phenolic

\section{INTRODUCTION}

Bee bread is a health-oriented bee product rich in nutritional value (Kieliszek et al., 2018). Bees produce this product by combining the pollen with their digestive enzymes and placing them in the comb cells (Vásquez \& Olofsson, 2009). Leucine aminopeptidase, acid phosphatase and alpha glucosidase have been reported as the most common digestive enzymes detected in honeybee workers (Gilliam et al., 1988). Three quarters of the cells are filled with the enzymepollen mixture and the remaining quarter is covered with honey. Thus, an anaerobic environment is formed, and lactic acid fermentation takes place (Vásquez \& Olofsson, 2009).

Bee bread is considered as a balanced food source since it consists of carbohydrates, fat, proteins, fatty acids and trace minerals necessary for human health (Čeksterytė \& Jansen, 1961). The composition varies depending on its botanical origin and seasonal conditions (Baltrušaitytè et al., 2007). It is the main food for larvae and young bees producing royal jelly in the hive. The nutritional value of bee bread is higher than bee pollen. It is a more digestible 
food due to its high free amino acid content and sugars that can be easily assimilated (Bakour et al., 2019). Bee bread contains proteins, fats and an abundance of carbohydrates and lactic acid. Bee bread show higher bioavailability than pollen and can be partially digested through fermentation (Khalifa et al., 2020). It also contains such minerals and vitamins as $C, B 1, B 2, E, H$, $P$, nicotinic acid, folic acid, and pantothenic acid (Nagai et al., 2004). Besides having a positive effect on the immune system, bee bread also shows antibiotic and antioxidant properties (Markiewicz-Żukowska et al., 2013).

The polyphenols, which are abundant in the structure of bee bread, are of medical interest. Among the polyphenols, flavonoids represent the most important group of compounds found in pollen and bee bread (Mărgăoan et al., 2019). Bee bread has been reported to have a high flavonoid content (Čeksteryté et al., 2016). Flavanoids and phenolic acids are examples of antioxidants, which are significant ingredients of many foods, and keenly sought in various health foods. Vela et al. (2007) have reported that they contribute to protecting against, among others, cancer, cardiovascular disorders, neurodegenerative diseases and ageing by mopping up potentially damaging free radicals that are released in the body.

Bee bread has the role of a major source of protein for bees and has demonstrated in vitro antibacterial, antioxidant, and antitumor properties (Sobral et al., 2017). Bee bread is a significant product due to its nutritional value, antioxidant properties and other mentioned properties. Recent, studies have drawn attention to its nutritional content and antioxidant properties. The quality information available in the literature concerning bee bread is generally based on its phenolic composition (Sobral et al., 2017). For this reason, bee bread samples collected from different parts of Anatolia were subjected to total phenolics, total flavonoids, total antioxidant capacity and nutritional analyses to determine the nutritional and antioxidant value of Anatolian bee bread.

Bee bread is not a well-known product in Turkey and production is limited to a few provinces. An assessment of the antioxidant properties of bee bread could draw attention to it. Bee bread samples obtained from different provinces of Turkey, where four distinct seasons are experienced, are expected to present regional differences in terms of nutritional and antioxidant properties. In this paper, it is aimed to evaluate the nutritional and antioxidant characteristics of Anatolian bee bread and present an examination of regional differences.

\section{MATERIAL AND METHODS}

\section{Materials}

Sodium carbonate anhydrous, sodium hydroxide, ammonium acetate and copper (II) chloride dehydrate were supplied from VWR Chemicals; formic acid, catechin and neocuproine from Sigma-Aldrich; gallic acid and sodium nitrite from Alfa Aesar; ethanol and Folin-Ciocalteu's reagent from Carlo Erba; and Trolox from Acros Organics.

\section{Sample preparation of bee bread}

Bee bread samples were collected from different regions of Anatolia including Muğla - prominent city in terms of honey production, Van representing the Eastern Anatolia region, Kırșehir and Sivas representing the Central Anatolia region in April and September of 2018 and 2019. Since bee bread is not a well-known product, its production is not common everywhere and the majority of bee bread production in Turkey is provided by beekeepers in the Muğla province. Therefore, while seven samples were provided from Muğla, one sample per city were provided from the other provinces.

Kırșehir lies at $38^{\circ} 50^{\prime}-39^{\circ} 50^{\prime} \mathrm{N}$ latitudes, $33^{\circ}$ $30^{\prime}-34^{\circ} 50^{\prime} \mathrm{E}$ longitudes and an altitude of 985 meters above sea level. Muğla lies at $37^{\circ} 12^{\prime} \mathrm{N}$ latitude, $28^{\circ} 21^{\prime} \mathrm{E}$ longitude and an altitude of 670 meters above sea level. Van lies at $42^{\circ} 40^{\prime}$ $44^{\circ} 30^{\prime}$ ' E longitudes, $37^{\circ} 43^{\prime}$ - $39^{\circ} 26^{\prime} \mathrm{N}$ latitudes and an altitude of 1730 meters above sea level. Sivas lies at $35^{\circ} 50^{\prime}-38^{\circ} 14^{\prime} \mathrm{E}$ longitudes, $38^{\circ}$ $42^{\prime}-40^{\circ} 16^{\prime} \mathrm{N}$ latitudes and an altitude of 1285 meters above sea level.

Bee bread from the hive was harvested with the use of a Wilara (JSC Birutès st. 5, Prienai, 
LT-59140) 2018 model bee bread machine. Bee bread samples collected periodically were grouped according to the region they were collected, and until the analysis period, they were stored at $-18^{\circ} \mathrm{C}$. Ten samples were prepared for total phenolic, flavonoid, antioxidant and moisture content analyzes. Since there was a limited number of samples for the analysis and the point was to focus on the antioxidant characteristics and their antioxidant value, nutritional content was analysed using a homogenous mixture representing ten samples.

For the extraction of bee bread samples, $1.5 \mathrm{~g}$ of a homogeneously mixed bee bread sample was weighed into a $15 \mathrm{~mL}$ centrifuge tube and $10 \mathrm{~mL}$ of $95 \%$ ethanol was added. In order to obtain a homogeneous structure, it was kept in an ultrasonic bath at $40^{\circ} \mathrm{C}$ for sixty minutes. These tubes were centrifuged at 5000 rpm for thirty minutes at $40^{\circ} \mathrm{C}$. The supernatants obtained thanks to this procedure in two replicates were collected in a $25 \mathrm{~mL}$ beaker. This mixture was completed to $25 \mathrm{~mL}$ with $95 \%$ ethanol. Prior to analysis, the mixtures were filtered through 45 um nylon filters (Zhou et al., 2015).

\section{Determination of moisture content}

Bee-bread samples of $5 \mathrm{~g}$ were analyzed with a SHIMADZU (Kyoto, Japan) MOC-63u moisture analyzer.

\section{Determination of total phenolics}

The analysis is based on the principle of measuring the concentration of the blue-colored molybdenum-tungsten complex formed through the oxidation of phenolic compounds with complex polymeric ions of phosphotungaustic and phosphomolybdic acids in the FolinCiocalteu solution.

The calibration curve was prepared with varying concentrations (0.25-0.13-0.06-0.03-0.02) of the gallic acid standard (0.5 mg/mL). $200 \mu \mathrm{L}$ of bee bread extract was placed in $15 \mathrm{~mL}$ analysis tubes. For the blank, $200 \mu \mathrm{L}$ extraction solutions were placed instead of the sample, and for the calibration curve, $200 \mu \mathrm{L}$ of varying concentrations of gallic acid were put into tubes. Then $1.5 \mathrm{~mL}$ of $0.2 \mathrm{~N}$ Folin solution was added to the tubes and left for five minutes, and the tubes were vortexed with the addition of $1.2 \mathrm{~mL}$ of $7.5 \% \mathrm{NaCO}_{3}$ solution. It was left for 90 minute incubation at room temperature in the dark and then read against the blank at a wavelength of $765 \mathrm{~nm}$ in the VWR (Radnor, Pennsylvania, United States of America) UP-6300PS spectrophotometer (Meda et al., 2005). The total phenolics were expressed as $\mathrm{mg}$ gallic acid equivalent (GAE) in $100 \mathrm{~g}$ sample.

\section{Determination of total flavonoids}

The analysis is based on the principle of the formation of a pink-colored flavonoid-aluminum complex in alkaline medium using aluminum chloride and sodium nitrite. The calibration curve was prepared with varying concentrations (0.10.08-0.05-0.02-0.01) of the catechin standard $(1 \mathrm{mg} / \mathrm{mL}) .1 \mathrm{~mL}$ bee bread extraction solutions were placed in $15 \mathrm{~mL}$ analysis tubes. For the blank, $1 \mathrm{~mL}$ of extraction solution was substituted for the sample. For the calibration curve, $1 \mathrm{~mL}$ of varying concentrations of catechin were placed in tubes. The timing was started with a stopwatch and $300 \mu \mathrm{L}$ of $5 \% \mathrm{NaNO}_{2}\left(\mathrm{t}_{0}=0\right), 300$ $\mu \mathrm{L}$ of $10 \% \mathrm{AlCl}_{3}\left(\mathrm{t}_{1}=5 \mathrm{~min}\right), 2 \mathrm{~mL}$ of $1 \mathrm{M} \mathrm{NaOH}$ $\left(t_{2}=6 \mathrm{~min}\right)$ and finally $2.4 \mathrm{~mL}$ pure water was added and mixed with vortex. The mixture was read against the blank at a wavelength of 510 $\mathrm{nm}$ in the spectrophotometer (Dewanto et al., 2002). The total flavonoid substance amount of bee bread extracts was expressed as mg catechin equivalent (CE) in $100 \mathrm{~g}$ sample. Each sample was run in three replicates.

\section{Determination of antioxidant activity}

The antioxidant capacity of bee bread samples was calculated through the utilization of the ability of the neocuproine complex (Cu(II)-Nc), formed by 2,9-dimethyl-1,10-phenanthroline (Neocuproine-Nc) with $\mathrm{Cu}(\mathrm{III})$, to be reduced to copper (I)- neocuproine [Cu(I)-Nc] chelate with a maximum absorbance of $450 \mathrm{~nm}$ (Apak et al., 2004).

The calibration curve was prepared with varying concentrations (0.5-0.25-0.13-0.06-0.03) of the Trolox standard (1 mg/mL). $100 \mu \mathrm{L}$ of bee bread extraction solutions were placed in $15 \mathrm{~mL}$ 
analysis tubes. For the blank, $100 \mu$ Lextraction solution was substituted for the sample. For the calibration curve, varying concentrations of Trolox were put into the tubes of $100 \mu \mathrm{L}$. Then $1 \mathrm{~mL}$ of $\mathrm{CuCl}_{2}, 1 \mathrm{~mL}$ of neocuproine, $1 \mathrm{~mL}$ of $\mathrm{NH}_{4} \mathrm{CH}_{3} \mathrm{COO}$ and $1 \mathrm{~mL}$ of distilled water were added and mixed through vortexing, respectively. The mixtures were incubated in the dark at room temperature for one hour. The mixture was read against the blank at a wavelength of $450 \mathrm{~nm}$ in the spectrophotometer UV-6300 PS spectrophotometer against the blank sample. The total antioxidant activity was expressed as mg Trolox equivalent antioxidant capacity (TEAC) in $100 \mathrm{~g}$ sample.

\section{Nutritional content analyses}

In order to determine the nutritional content of Anatolian bee bread, ten samples were mixed and carbohydrate, fat (ASU L 06.00-6), saturated fat (AOAC 969.33), fiber (AOAC 985.29), protein (Kjeldahl, protein factor is 6.25), salt (DIN EN 15763 mod.), ash (Gravimetry), iron (DIN EN 15763 mod.) and zinc (DIN EN 15763 mod) analyses were performed. The total carbohydrate content and total energy were calculated with the use of the formulas given below (Mohammad et al., 2020).

g carbohydrates $=100 \mathrm{~g}-($ moisture $+\mathrm{glipid}+\mathrm{g}$ protein $+g$ ash).

Total energy $(\mathrm{kcal} / 100 \mathrm{~g})=(\%$ protein $\times 4)+(\%$ carbohydrates $\times 4)+(\%$ fat $\times 9)$

\section{Statistical analysis}

Statistical evaluations of bee breads were performed according to the randomized pilot trial pattern in three replicates in each group. The differences between the groups were determined with ANOVA variance analyses (Düzgüness et al., 1987). In the analysis of variance, least significant difference test (LSD) was performed for parameters where the differences between groups were statistically significant. In addition, a pilot chart was created based on principal component analysis (PCA) among the samples. JMP (version 11) statistics package program was used for ANOVA, LSD and PCA evaluations.

\section{RESULTS}

Total flavonoids, phenolics, antioxidants and moisture content results are given in Tab. 1 . In this study, total phenolic, total flavonoid substance, total antioxidant and moisture contents were detected in the ranges of $11.90-14.77 \mathrm{mg} \mathrm{GAE} / \mathrm{g}, 1.30-6.30 \mathrm{mg} \mathrm{CE} / \mathrm{g}$, 20.03-35.43 mg TEAC/g and 10.13 and 18.10\%,

Table 1.

Total flavonoids, phenolics, antioxidants and moisture content of bee bread samples

\begin{tabular}{ccccc}
\hline Sample* & $\begin{array}{c}\text { Total Phenolics } \\
(\mathrm{mg} \mathrm{GAE} / \mathrm{g})\end{array}$ & $\begin{array}{c}\text { Total Flavonoids } \\
(\mathrm{mg} \text { CE/g) }\end{array}$ & $\begin{array}{c}\text { Total Antioxidants } \\
(\mathrm{mg} \mathrm{TEAC/g)}\end{array}$ & $\begin{array}{c}\text { Moisture Content } \\
(\%)\end{array}$ \\
Van & $12.60 \pm 0.26^{\mathrm{C}}$ & $\begin{array}{c}4.53 \pm 0.35^{\mathrm{B}} \\
27.77 \pm 0.35^{\mathrm{C}}\end{array}$ & $10.80 \pm 0.30^{\mathrm{E}}$ \\
Kırșehir & $13.30 \pm 0.36^{\mathrm{B}}$ & $3.57 \pm 0.23^{\mathrm{C}}$ & $25.30 \pm 0.10^{\mathrm{D}}$ & $10.13 \pm 0.38^{\mathrm{F}}$ \\
Sivas & $12.37 \pm 0.45^{\mathrm{CD}}$ & $2.57 \pm 0.40^{\mathrm{D}}$ & $23.23 \pm 0.31^{\mathrm{E}}$ & $14.33 \pm 0.31^{\mathrm{CD}}$ \\
Muğla 1 & $14.77 \pm 0.31^{\mathrm{A}}$ & $5.03 \pm 0.42^{\mathrm{B}}$ & $32.33 \pm 0.38^{\mathrm{B}}$ & $13.80 \pm 0.35^{\mathrm{D}}$ \\
Muğla 2 & $14.77 \pm 0.35^{\mathrm{A}}$ & $6.03 \pm 0.31^{\mathrm{A}}$ & $35.43 \pm 0.40^{\mathrm{A}}$ & $15.23 \pm 0.40^{\mathrm{B}}$ \\
Muğla 3 & $12.50 \pm 0.36^{\mathrm{CD}}$ & $1.43 \pm 0.38^{\mathrm{E}}$ & $24.00 \pm 0.53^{\mathrm{E}}$ & $15.37 \pm 0.38^{\mathrm{B}}$ \\
Muğla 4 & $14.43 \pm 0.25^{\mathrm{A}}$ & $6.03 \pm 0.25^{\mathrm{A}}$ & $32.30 \pm 0.35^{\mathrm{B}}$ & $14.43 \pm 0.38^{\mathrm{C}}$ \\
Muğla 5 & $13.33 \pm 0.21^{\mathrm{B}}$ & $1.37 \pm 0.25^{\mathrm{E}}$ & $25.27 \pm 0.29^{\mathrm{D}}$ & $13.77 \pm 0.32^{\mathrm{D}}$ \\
Muğla 6 & $11.90 \pm 0.53^{\mathrm{D}}$ & $1.30 \pm 0.26^{\mathrm{E}}$ & $20.03 \pm 1.63^{\mathrm{F}}$ & $17.57 \pm 0.31^{\mathrm{A}}$ \\
Muğla 7 & $12.60 \pm 0.46^{\mathrm{C}}$ & $5.63 \pm 0.40^{\mathrm{A}}$ & $27.80 \pm 0.36^{\mathrm{C}}$ & $18.10 \pm 0.36^{\mathrm{A}}$ \\
\hline
\end{tabular}

Different letters in the same line refers to significant differences between the averages $(P<0.05)$.

* Samples are named according to the Anatolian provinces where they were collected. 
Table 2.

Nutritional content of Anatolian bee bread

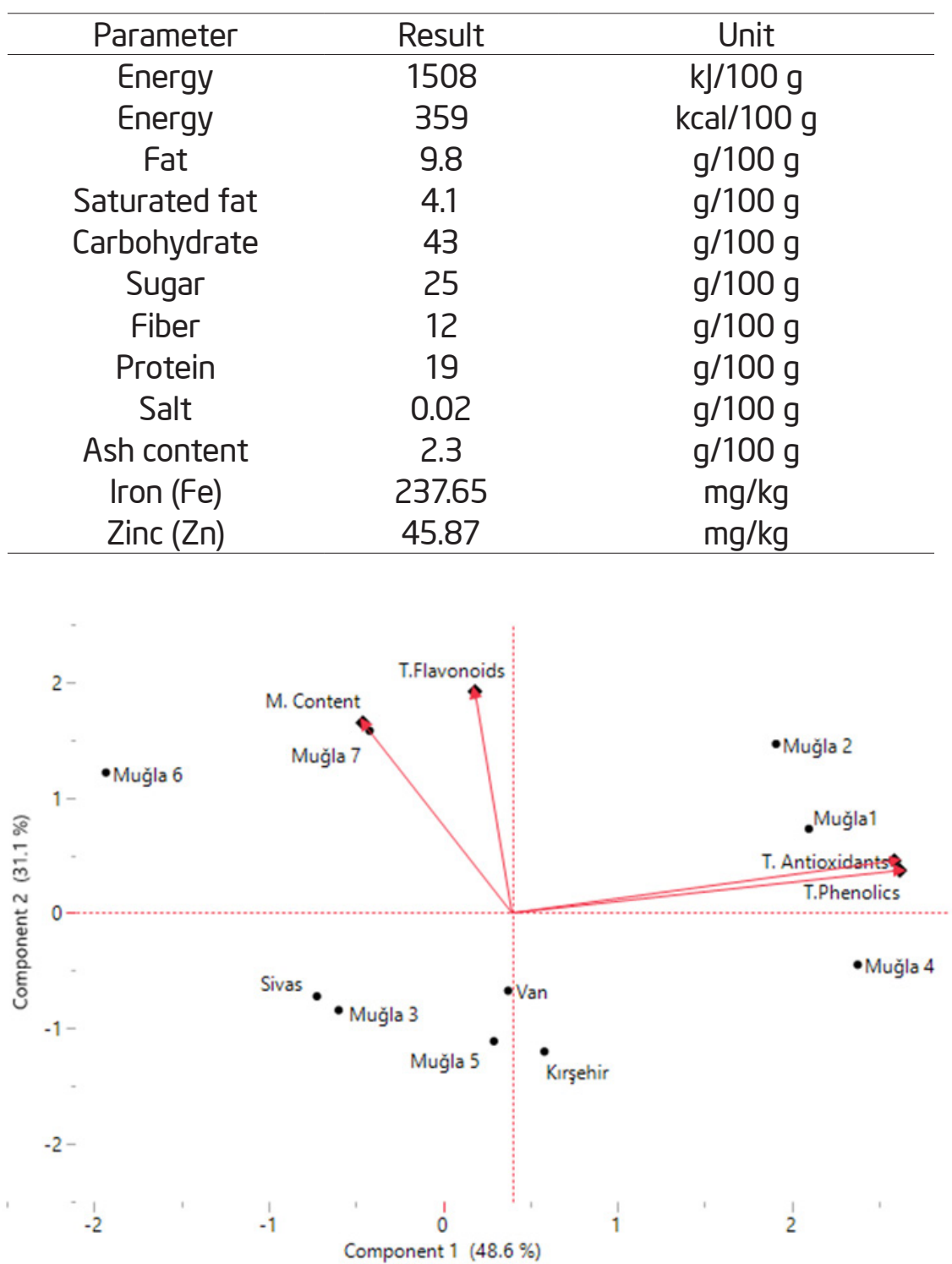

Fig. 1. PCA results (Bi-plot) on the investigated samples.

respectively. PCA results given in Tab. 1 and Fig. 1 reveals that Muğla1, Muğla2 and Muğla4 bee bread samples present higher values compared to samples collected from other locations in terms of total phenolic and total antioxidant content. The nutritional content of bee bread analyzed in this paper is given in Tab. 2 .

\section{DISCUSSION}

In a study conducted by Bakour et al. (2017), chemical analysis showed that the bee bread samples obtained from Morocco contained a moisture content of $9.85 \%$, fat content of $2.31 \%$, carbohydrate content of $28.46 \%$, protein content of $12.81 \%$ and fiber content of $8.30 \%$. In the present study, carbohydrate, fat, and protein contents were found as 43\%, 9.8\% and $19 \%$ respectively, which are significantly higher compared to the results of the Morocco samples. Total phenolic, flavonoid and antioxidant contents of Muğla1, Muğla2 and Muğla4 bee bread samples were found to be higher compared to those of other bee samples. This difference indicates that the pollen variety and plant diversity is very high in the region where Muğla1, Muğla2 and Muğla4 bee bread samples were collected (Mayda et al., 2019).

Muğla bee bread samples, which have the 
highest content in terms of total phenolic and total flavonoids, were determined to be the highest in terms of total antioxidant activity compared to other bee bread samples. Average humidity content of the bee breads obtained from the provinces of Van, Sivas and Kirșehir in the Eastern and Central Anatolia regions was found to be lower than the average humidity of the samples obtained from the Muğla city in Western Anatolia region. This situation can be explained by the fact that the Western Anatolia region is more rainy and humid than the Central and Eastern Anatolia regions.

A comparison of the bee breads for total phenolic, total flavonoid and antioxidant based on the provinces where they were collected clearly demonstrated that Muğla1, Muğla2 and Muğla4 bee bread samples had higher content than Van, Kirșehir and Sivas samples. This is due to the fact that this region (Muğla1, Muğla2 and Muğla4 locations) has greater plant diversity and pollen variety with high antioxidant content. In a study conducted by Ivanišová et al. (2015), the total phenolic content of bee bread collected from different regions of Ukraine ranged from 12.36 to $25.44 \mathrm{mg} \mathrm{GAE} / \mathrm{g}$, the total flavonoid content from 13.56 to $18.24 \mathrm{mg} Q E / g$ and total antioxidant activitys from 5 to $15.78 \mathrm{mg} \mathrm{TEAC/g}$. Markiewicz et al. (2013) determined that the phenolic content of bee bread samples collected from different regions of Poland ranged from 32.78 to $37.15 \mathrm{mg} G A E / g$ and that the antioxidant effect was dependent not only on the phenolic substance content but also on the non-phenolic substance content. Total phenolic content, total flavonoid content, antioxidant activity and moisture content of bee breads collected from different regions of Colombia were found to be in the ranges of 2.5-13.7 mg GAE/g, 1.9-4.5 mg QE/g, 46.1-76.3 $\mu \mathrm{mol}$ TEAC/g and 7.8 -19.1\%, respectively (Zuluaga et al., 2015). Mayda (2019) studied the bee bread samples collected from Ankara, Bursa and Kırklareli cities of Turkey and found that total phenolic content, total flavonoid content, antioxidant capacity and moisture content ranged between 82.57-127.07 $\mathrm{mg}$ GAE/g, 1.81-3.74 mg QE/g, 1.29-3.82 mg TEAC/g and 17.5-21.2\%, respectively.
In this paper, the antioxidant content of bee bread samples was higher than the results by Ivanišová et al. (2015) and Mayda (2019) whereas it was lower than the results by Zuluaga et al. (2015). Moisture content was found in the range determined by Zuluaga et al. (2015).

According to the findings obtained in this study, bee-bread samples' phenolic substance, flavonoid and antioxidant content differ according to the provinces where they were obtained. At the same time, difference were observed with findings in the above-mentioned studies on bee bread samples collected from Ukraine, Poland, Colombia and Turkey. Bakkaloğlu \& Arıcı (2019) stated that a region's geographical location where bee bread is gathered, climate and vegetation diversity constitute the main sources of this difference.

Andjelkovic et al. (2015) analyzed the nutritional composition of bee bread from Makrešane and found Fe and $\mathrm{Zn}$ contents to be $121.99 \mathrm{mg} / \mathrm{kg}$ and $44.09 \%$, respectively. In the present study, Fe and $\mathrm{Zn}$ contents of Anatolian bee bread samples were found to be $237.65 \mathrm{mg} / \mathrm{kg}$ and $45.87 \mathrm{mg} / \mathrm{kg}$, respectively. This comparison clearly shows that bee bread samples collected from Anatolia have an abundance of Fe and $\mathrm{Zn}$. In the study on bee bread collected from different regions of Anatolia, the nutritional and antioxidant properties of samples were analyzed, and the results were compared with other studies in the literature. The antioxidant capacity of Anatolian bee bread was concluded to be higher compared to other sources while the moisture content was lower. Anatolian bee bread was found to have a valuable nutritional content. The Fe and $\mathrm{Zn}$ content of bee bread samples were higher compared to that in literature. In this study, it was determined that there is a positive correlation between the phenolic, flavonoid content and antioxidant activity of bee bread. In addition, it has been revealed that Muğla, which is one of Anatolia's (Turkey) major honey production centers could be a substantial production center for bee bread with high antioxidant content.

With the increased consumer awareness, there is a trend towards natural products with high nu- 
tritional value. Bee bread is a bee product with high nutritional and economical value among natural products but is less known and has been little researched. With this study, the antioxidant properties of bee bread were confirmed. The findings of the study support that bee bread is a highly nutritional product. The study results confirm the advantages of the use of bee bread in apitherapy. Interest in alternative treatment methods in the world is increasing day by day, and bee bread is among the natural probiotics used in daily diet since it has valuable probiotic microorganisms in its content. Rich in phenolic and flavonoid content, antioxidant capacity and nutritional value, bee bread contributes to improving the quality of life.

\section{ACKNOWLEDGEMENTS}

This study was supported by SBS Bilimsel Bio Cozumler R\&D Center.

\section{REFERENCES}

Andjelkovic, B., Jevtic, G., Markovic, J., Mladenovic, M., Pseva, V. (2015). Quality of honeybee bread collected in spring. In Proceedings of the International Symposium on Animal Science 2014, September 2014, Belgrade-Zemun, www.livestocksym.com

Apak, R., Güçlü, K., Özyürek, M., Karademir, S. E. (2004). Novel total antioxidant capacity index for dietary polyphenols and vitamins $C$ and $E$, using their cupric ion reducing capability in the presence of neocuproine: CUPRAC method. Journal of Agricultural and Food Chemistry, 52(26), 79707981. https://doi.org/10.1021/jf048741x

Bakkaloğlı, Z., \& Arıcı, M., (2019). Farkı Çözücülerle Propolis Ekstraksiyonunun Toplam Fenolik Içeriği, Antioksidan Kapasite ve Antimikrobiyal Aktivite Üzerine Etkileri. Akademik Gıda, 174), 538-545. https://doi.org/10.24323/akademik-gida.667272

Bakour, M., Al-Waili, N. S., El Menyiy, N., Imtara, H., Figuira, A. C., Al-Waili, T., Lyoussi, B. (2017). Antioxidant activity and protective effect of bee bread (honey and pollen) in aluminum-induced anemia, elevation of inflammatory makers and hepato-renal toxicity. Journal of Food Science and Technology, 54(13), 4205-4212. https://doi. org/10.1007/s13197-017-2889-9

Bakour, M., Fernandes, Â., Barros, L., Sokovic, M., Ferreira, I. C. (2019). Bee bread as a functional product: Chemical composition and bioactive properties. LWT, 109, 276-282. https://doi. org/10.1016/j.lwt.2019.02.008

Baltrušaitytè, V., Venskutonis, P. R., Čeksterytè, V. (2007). Radical scavenging activity of different floral origin honey and beebread phenolic extracts. Food Chemistry, 101(2),502-514.https://doi.org/10.1016/j. foodchem.2006.02.007

Čeksterytè, V., \& Jansen, E. H.J. M. (2012). Composition and content of fatty acids in beebread of various floral origin, collected in Lithuania and prepared for storage indifferent ways. Chemine Technologija, Z(60), 57-61. http://dx.doi.org/10.5755/j01. ct.60.2.1961

Čeksteryté, V., Kurtinaitienè, B., Venskutonis, P. R., Pukalskas, A., Kazernavičiūtè, R., Balžekas, J. (2016). Evaluation of antioxidant activity and flavonoid composition in differently preserved bee products. Czech Journal of Food Sciences, 34(2), 133-142. https://doi.org/10.17221/312/2015-CJFS

Dewanto, V., Wu, X., Adom, K. K., Liu, R. H. (2002). Thermal processing enhances the nutritional value of tomatoes by increasing total antioxidant activity. Journal of Agricultural and Food Chemistry, 5010), 3010-3014. https://doi. org/10.1021/jf0115589

Düzgüneș, O. Kesici, T., Kavuncu, O. ve Gürbüz, $F$. (1987). Araștırma ve Deneme Metotları (Istatistik Metotları-II), Ankara Üniversitesi, Ziraat Fakültesi Yayınları: 1021, Ders kitabı, Ankara, 495 s.

Gilliam, M., Lorenz, B. J., Richardson, G. V. (1988). Digestive enzymes and micro-organisms in honey bees, Apis mellifera influence of streptomycin, age, season and pollen. Microbios, 55(223), 95-114. 
Ivanišová, E., Kačániová, M., Frančáková, H., Petrová, J., Hutková, J., Brovarskyi, V., ... Musilová, J. (2015). Bee bread-perspective source of bioactive compounds for future. Potravinarstvo Slovak Journal of Food Sciences, 9(1), 592-598. https://doi. org/10.5219/558

Khalifa, S. A., Elashal, M., Kieliszek, M., Ghazala, N. E., Farag, M. A., Saeed, A., ... El-Seedi, H. R. (2020). Recent insights into chemical and pharmacological studies of bee bread. Trends in Food Science \& Technology, 97,300-316. https://doi.org/10.1016/j. tifs.2019.08.021

Kieliszek, M., Piwowarek, K., Kot, A. M., Błażejak, S., Chlebowska-Śmigiel, A., Wolska, I. (2018). Pollen and bee bread as new health-oriented products: A review. Trends in Food Science \& Technology, 71, 170-180. https://doi.org/10.1016/j.tifs.2017.10.021

Mărgăoan, R., Stranț, M., Varadi, A., Topal, E., Yücel, B., Cornea-Cipcigan, M., ... Vodnar, D. C. (2019). Bee collectedpollenandbeebread:Bioactiveconstituents and health benefits. Antioxidants, 8(12), 568. https://doi.org/10.1016/j.tifs.2017.10.021

Markiewicz-Żukowska, R., Naliwajko, S. K., Bartosiuk, E., Moskwa, J., Isidorov, V., Soroczyńska, J., Borawska, M. H. (2013). Chemical composition and antioxidant activity of beebread, and its influence on the glioblastoma cell line (U87MG). Journal of Apicultural Science, 572), 147-157. https://doi.org/10.2478/jas2013-0025

Mayda N., Keskin M., Keskin Ș., Özkök, A. (2019). Determination of botanic origins, total phenolic and flavonoid contents of bee pollen collected from the Bilecik province. Uludağ Arıcilik Dergisi (Uludag Bee Journal), 19(2), 152-160. (In Turkish) https://doi. org/10.31467/uluaricilik.605692

Mayda, N. (2019). Determination of Palynological, Chemical and Antioxidant Capacities of Bee Pollen and Bee Bread. Master thesis. Hacettepe University/Ankara (Web Page: http://hdl.handle. net/11655/21861).

Meda, A., Lamien, C. E., Romito, M., Millogo, J.,
Nacoulma, O. G. (2005). Determination of the total phenolic, flavonoid and proline contents in Burkina Fasan honey, as well as their radical scavenging activity. Food Chemistry, 97(3), 571-577. https:// doi.org/10.1016/j.foodchem.2004.10.006

Mohammad, S. M., Mahmud-Ab-Rashid, N. K., Zawawi, N. (2020). Botanical origin and nutritional values of bee bread of stingless bee (Heterotrigona itama) from Malaysia. Journal of Food Quality, 2020, Article ID2845757.https://doi.org/10.1155/2020/2845757

Nagai, T., Nagashima, T., Myoda, T., Inoue, R. (2004). Preparation and functional properties of extracts from bee bread. Food/Nahrung, 48(3), 226-229. https://doi.org/10.1002/food.200300421

SAS Institute., (2014). JMP statistical software, version 11. SAS Institute. Inc., Cary, North Carolina, USA.

Sobral, F., Calhelha, R. C., Barros, L., Dueñas, M., Tomás, A., Santos-Buelga, C., Vilas-Boas, M., Ferreira, I. C. (2017). Flavonoid composition and antitumor activity of bee bread collected in northeast Portugal. Molecules, 22(2), 248. https://doi. org/10.3390/molecules22020248

Vela, L., de Lorenzo, C., Perez, R. A. (2007). Antioxidant capacity of Spanish honeys and its correlation with polyphenol content and other physicochemical properties. Journal of the Science of Food and Agriculture, 876), 1069-1075. https:/l doi.org/10.1002/jsfa.2813

Vásquez, A., \& Olofsson, T. C. (2009). The lactic acid bacteria involved in the production of bee pollen and bee bread. Journal of Apicultural Research, 48(3), 189-195. https://doi.org/10.3896/IBRA.1.48.3.07

Zhou, J., Qi, Y., Ritho, J., Zhang, Y., Zheng, X., Wu, L., ... Sun, L. (2015). Flavonoid glycosides as floral origin markers to discriminate of unifloral bee pollen by LC-MS/MS. Food Control, 57, 54-61. https://doi. org/10.1016/j.foodcont.2015.03.035

Zuluaga, C. M., Serratob, J. C., Quicazana, M. C. (2015). Chemical, nutritional and bioactive characterization 
of Colombian bee-bread. Chemical Engineering, 43, 175-180. DOl: 10.3303/CET1543030 